\title{
Successful Treatment of Traumatic Neuroma
}

\author{
Jiří Šedý
}

Published online: 12 April 2009

(C) Société Internationale de Chirurgie 2009

Vuilleumier et al. [1] performed a prospective cohort study on 43 consecutive patients who underwent surgical revision, mesh removal, and radical neurectomy as a treatment for persistent neuropathic pain after primary herniorrhaphy. During a 1-year postoperative follow-up period, 41 patients (95\%) experienced complete pain relief, whereas 2 patients noted only partial improvement [1].

These excellent results, in particular their observations that "nerves can be difficult to identify where they are entrapped in the scar tissue or in the mesh prosthesis" [1] as well as "to prevent nerve scarring within the operative field, the proximal transected nerve ends should be ligated and buried within the fibers of the internal oblique muscle" [1] are of particular interest to our group, examining the mechanism of traumatic neuroma development. Their results clearly correspond to our hypothesis postulating that traumatic neuroma development involves simultaneous nerve repair and defensive mechanisms (i.e., reactive proliferation of perineurial cells) in the region of concomitant wound and scar contraction [2]. Moreover, by their surgical approach, they disrupted the proposed "easily violable balance between nerve regeneration and damage" [2] and obtained a long-term treatment effect. In conclusion, I would like to congratulate the authors on their results, which reflect their top-rated skills, necessary to perform a meticulous surgery in the field of previous operation.

\section{References}

1. Vuilleumier H, Hübner M, Demartines N (2009) Neuropathy after herniorrhaphy: indication for surgical treatment and outcome. World J Surg. doi:10.1007/s00268-008-9869-1

2. Foltán R, Klíma K, Špačková J, Šedý J (2008) Mechanism of traumatic neuroma development. Med Hypotheses 71:572-576

Comment on: Vuilleumier H, Hübner M, Demartines N. Neuropathy after herniorrhaphy: indication for surgical treatment and outcome. World J Surg (in press)

\section{J. Šedý (四)}

Institute of Experimental Medicine, Academy of Sciences of the Czech Republic, Vídeňská 1083, 14220 Prague 4,

Czech Republic

e-mail: jirisedy@hotmail.com 